\title{
Geology and geotechnical evaluation of Doha rock formations
}

Nikolaos Karagkounis MSc, DIC, PMP

Senior Geotechnical Engineer, Ground Engineering, WS Atkins \& Partners Overseas, Doha, Qatar

Benoît Latapie MSc, Eurlng

Technical Manager, Ground Engineering, WS Atkins \& Partners Overseas, Dubai, UAE (corresponding author: benoit.latapie@atkinsglobal.com)

\section{Kevin Sayers MBA}

Technical Director, WS Atkins \& Partners Overseas, Doha, Qatar Sainath Reddy Mulinti MEng

Geotechnical Engineer, Ground Engineering, WS Atkins \& Partners Overseas, Doha, Qatar

A generalised ground model with geotechnical characterisation has been developed for the city of Doha, in Qatar, combining a wide range of ground investigation data and observations during the construction of projects that WS Atkins \& Partners Overseas were involved with. The model proposes a geotechnical characterisation and ranges of parameters for the main units found at depths relevant to civil engineering activities. A geotechnical classification system is proposed to differentiate the Simsima Limestone subunits encountered on site, based on rock quality designation (RQD) values and weathering degree. The proposed classification system and the relevant geotechnical parameters have been validated during construction. The construction of all excavations, temporary retaining systems and tunnel excavations that rely on the information presented in this paper has been completed successfully. This confirmed a reasonable agreement between the theory presented in the paper and the practical conditions encountered on site. Best site investigation practices are discussed with highlights on difficulties encountered on site and how they were resolved. RQD and rock mass rating values were found to produce a good representation of the ground conditions while the applicability of the geological strength index classification is believed to be limited.

\section{Notation}

$c^{\prime} \quad$ cohesion

$D$ disturbance factor

$E_{\mathrm{i}} \quad$ intact Young's modulus

$E_{\mathrm{RM}} \quad$ rock mass Young's modulus

$I_{\mathrm{s}, 50} \quad$ point load index

$K_{0} \quad$ coefficient of at-rest earth pressures

$k$ permeability

$m_{\mathrm{i}} \quad$ material constant

$\mathrm{RMR}_{89}^{\prime}$ rock mass rating designation

$\gamma$ density

$\phi^{\prime} \quad$ angle of internal friction

$v \quad$ Poisson's ratio

\section{Introduction}

The available literature on the geological and geotechnical setting in the city of Doha, the capital of Qatar, is limited. However, the construction boom of the recent years has and continues to require an extensive amount of ground investigation works to be carried out to inform the corresponding civil engineering works. WS Atkins \& Partners Overseas (Atkins) has been involved with many of these investigations and works accumulating vast regional geotechnical experience. The information presented in this paper is based on extensive data extracted from more than 1000 boreholes,
$45000 \mathrm{~m}$ of drilled core, 50000 in situ and laboratory tests and $150 \mathrm{~km}$ of geophysical surveys. In this paper, a general assessment of the geological setting and the geotechnical characteristics of the ground in Doha is presented, focusing on rock engineering aspects. As some of the projects Atkins has been involved with are still ongoing, site-specific references and project-specific factual details are not included in this paper. The information presented is general and does not pertain to any project in particular.

Topics such as hydrological conditions and known geohazards are discussed, and suggestions for further research are included. An attempt is made to provide typical ranges of key ground engineering parameters as well as a classification method for Simsima Limestone to aid geotechnical designers operating in Doha. Finally, some of the challenges encountered during ground investigation and proposed solutions are discussed.

\section{Geological setting}

\section{Geological units and topography}

The Qatar peninsula is geologically part of the Arabian Gulf Basin, which has been accumulating carbonate and evaporitic sediments since the Cambrian age with a thickness of sedimentary succession estimated to be over $10 \mathrm{~km}$ (Cavellier et al., 1970; Fourniadis, 2010). 
Geologically, Qatar belongs to the relatively stable Arabian interior platform. The country's rock formations have been subjected to a gentle but long lasting tectonic activity.

The resulting folding along with erosion processes have determined the topography of the peninsula, which is governed by the Qatar Dom anticline structure. This broad anticline has a north-south axis and is gently dipping towards the east and west. Doha is situated on the eastern basin of the anticline stretching from sea level to the east and reaching a maximum elevation of about $30 \mathrm{~m}$ above sea level to the west towards the anticline axis. Smaller scale gentle folds are found within the anticline structure, while no faults at depths relative to construction activities have been identified. At these depths, the geological units are of Palaeogene to Quaternary age. Quaternary units are found on or close to the surface and, in Doha, are mainly made ground, marine sediments and residual soil. The underlying bedrock units are largely horizontal to gentle dipping marine carbonates and evaporites comprising limestones, shales, siltstones, claystones, marls and gypsum.

The Simsima Limestone member of the Upper Dammam Formation outcrops over $80 \%$ of the land surface of Qatar, including the Doha area, and, due to its thickness and geotechnical properties, has been the main founding stratum for most developments in the area. The Upper Dammam Formation is underlain by the Lower Dammam Formation, which is in turn underlain by the Rus Formation (Fourniadis, 2010). This stratigraphic succession is consistent throughout Doha since it has not been disturbed by the gentle tectonic movements. Nevertheless, there is spatial variance in the thickness and geological characteristics of these formations owing to depositional, diagenetic and erosion factors. In particular, the Lower Dammam Formation can be completely locally eroded.

The general stratigraphy of Doha is presented in Table 1, which is based on a study by Cavellier et al. (1970). In the last column of

\begin{tabular}{|c|c|c|c|c|c|}
\hline Age & Formation & Member & Thickness: m & Lithology & $\begin{array}{c}\text { Doha } \\
\text { geotechnical } \\
\text { formations }\end{array}$ \\
\hline \multicolumn{6}{|c|}{ Quaternary } \\
\hline Holocene & & & & Mobile sands, bioclastic beach sands, soil & $\begin{array}{l}\text { Quaternary } \\
\text { deposits }\end{array}$ \\
\hline Pleistocene & & & & $\begin{array}{l}\text { Fixed dune sands, depression soils, cemented beach } \\
\text { rocks }\end{array}$ & $\begin{array}{l}\text { Quaternary } \\
\text { deposits }\end{array}$ \\
\hline \multirow{6}{*}{$\begin{array}{l}\text { Lower } \\
\text { Miocene }\end{array}$} & Lower & & $0-30 ;$ not & Fossiliferous marls, clays and thin limestone- outliers & - \\
\hline & Dam & & $\begin{array}{l}\text { present in } \\
\text { Doha }\end{array}$ & $\begin{array}{l}\text { only; occasional green and red clay bands in the } \\
\text { southwest }\end{array}$ & \\
\hline & \multicolumn{5}{|c|}{ Tertiary } \\
\hline & $\begin{array}{l}\text { Upper } \\
\text { Dammam }\end{array}$ & $\begin{array}{l}\text { Abarug } \\
\text { Limestone, } \\
\text { Abarug Marl }\end{array}$ & $\begin{array}{l}\text { Eroded; not } \\
\text { present in } \\
\text { Doha }\end{array}$ & $\begin{array}{l}\text { Grey brown, hard dolomitic limestone; white to yellow, } \\
\text { soft clayey chalky dolomitic marl }\end{array}$ & - \\
\hline & & Simsima & 30 & Buff to pale brown chalky crystalline limestone with & Simsima \\
\hline & & Limestone & & siltstone inclusions, variably dolomitic & Limestone \\
\hline \multirow{7}{*}{$\begin{array}{l}\text { Middle } \\
\text { Eocene }\end{array}$} & Lower & Dukhan & $0-1$ & White compact fossiliferous chalky limestone & Simsima \\
\hline & Dammam & Alveolina & & & Limestone \\
\hline & & Limestone & & & Formation \\
\hline & & Midra Shale & $0-10$ & $\begin{array}{l}\text { Yellow brown, laminated occasional fissile shale; } \\
\text { fossiliferous with limonite and phosphate nodules }\end{array}$ & $\begin{array}{l}\text { Midra Shale } \\
\text { Formation }\end{array}$ \\
\hline & & Fahail Velates & $0-1$ & White, crystalline compact fossiliferous limestone & Midra Shale \\
\hline & & Limestone & & & Formation \\
\hline & & Khor Limestone & 1 & $\begin{array}{l}\text { Buff to grey brown, massive pitted vesicular dolomitic } \\
\text { limestone }\end{array}$ & $\begin{array}{l}\text { Rus Limestone } \\
\text { Formation }\end{array}$ \\
\hline \multirow[t]{2}{*}{$\begin{array}{l}\text { Lower } \\
\text { Eocene }\end{array}$} & Rus & $\begin{array}{l}\text { Carbonate } \\
\text { facies }\end{array}$ & Up to 20 & $\begin{array}{l}\text { Cyclic deposition of weak carbonate marls siltstones } \\
\text { and thin limestone and chalk }\end{array}$ & $\begin{array}{l}\text { Rus Limestone } \\
\text { Formation }\end{array}$ \\
\hline & & Sulfate facies & Up to 100 & $\begin{array}{l}\text { Thick deposits of anhydrite and gypsum with marl and } \\
\text { thin limestone }\end{array}$ & $\begin{array}{l}\text { Rus Gypsum } \\
\text { Formation }\end{array}$ \\
\hline
\end{tabular}

Table 1. Summary of geological succession 
Geology and geotechnical evaluation of

Doha rock formations

Karagkounis, Latapie, Sayers and Mulinti
Table 1, the members have been combined into geotechnical formations considered suitable for most geotechnical analysis purposes for the city of Doha area. Differentiation to further formations might be required for more detailed/sensitive analysis depending on the design objectives. Table 2 presents core photographs of the main Geotechnical Formations encountered on civil engineering projects in Doha.

\section{Discontinuities}

The majority of discontinuities in Doha are horizontal to subhorizontal. Their formation is related to layering, tectonic uplift, overburden relief and gentle large-scale folding. The persistence of the discontinuities is further affected by groundwater flow and weathering processes and is typically between several metres to several tens of metres. Inclined fractures are also present but are less frequent and less persistent. At the considered depths, no faults have been identified. Local secondary processes, such as karst, may result in the formation of non-typical discontinuities.

Discontinuities of the following orientations have been identified

(a) horizontal to subhorizontal along bedding planes

(b) subhorizontal undulating discontinuities that can partly run along bedding planes and are related to tectonic uplift relaxation (these discontinuities are mostly observed in the Simsima Limestone Formation)

(c) subvertical discontinuities of low persistency encountered in all layers and related to the tectonic regime or secondary processes accompanied by volume loss (d) joints developed due to movements to accommodate bigger scale volume decrease owing to collapsed karstic cavities, mainly in the Rus sulfate facies; such joints have been observed in the Rus, and the observed characteristics are as follows

(i) inclination close to $45^{\circ}$

(ii) water bearing with deposited material on the discontinuity faces typically of dark colour

(iii) variable orientation governed by their relative positioning to the collapsed feature

(iv) such discontinuities can be associated with increased bedding inclination, which is atypical of the Doha ground conditions. This increased bedding inclination is expected to be towards the collapsed feature. These are also the only discontinuities in Doha along which movement may have occurred that could have resulted in smooth discontinuity surfaces. It is possible that discontinuities of this origin may also be found in the Simsima Formation, but they have not been observed. Instead, alleged Rus Gypsum Formation (RUS GYP) dissolution features have been related to increased thickness of highly weathered Simsima Limestone (HWSL) material that could, however, have been initiated from fracturing.

\section{Hydrogeological conditions}

At the concerned depths, the hydrogeological units encountered from the surface downwards are typically a perched aquifer in the Quaternary deposits, an unconfined aquifer in the Simsima Limestone Formation, an aquitard in the Midra Shale Formation and an underlying partially confined aquifer in the Rus Formation (Figure 1).

Simsima Limestone Formation

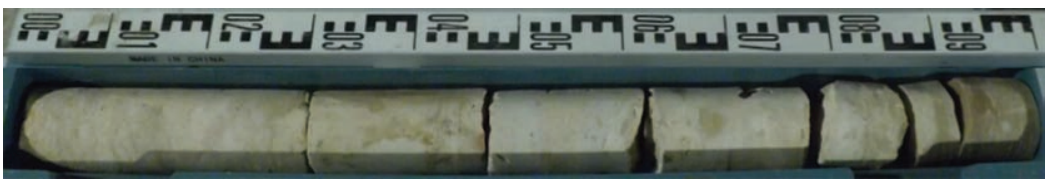

Midra Shale Formation

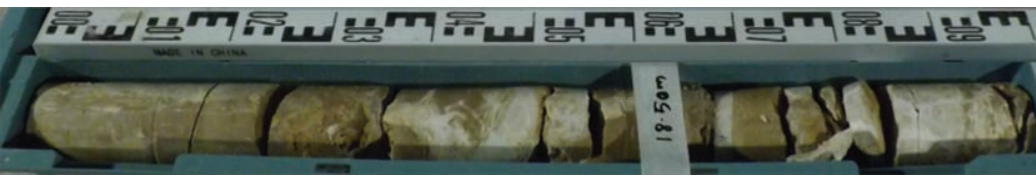

Rus Limestone Formation

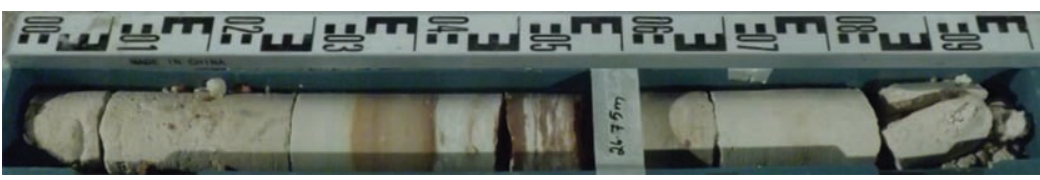

Rus Gypsum Formation

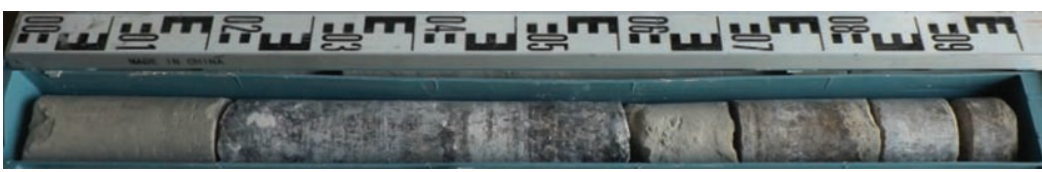

Table 2. Core photographs examples of Doha geotechnical

Formations as defined in Table 1 
Geology and geotechnical evaluation of

Doha rock formations

Karagkounis, Latapie, Sayers and Mulinti

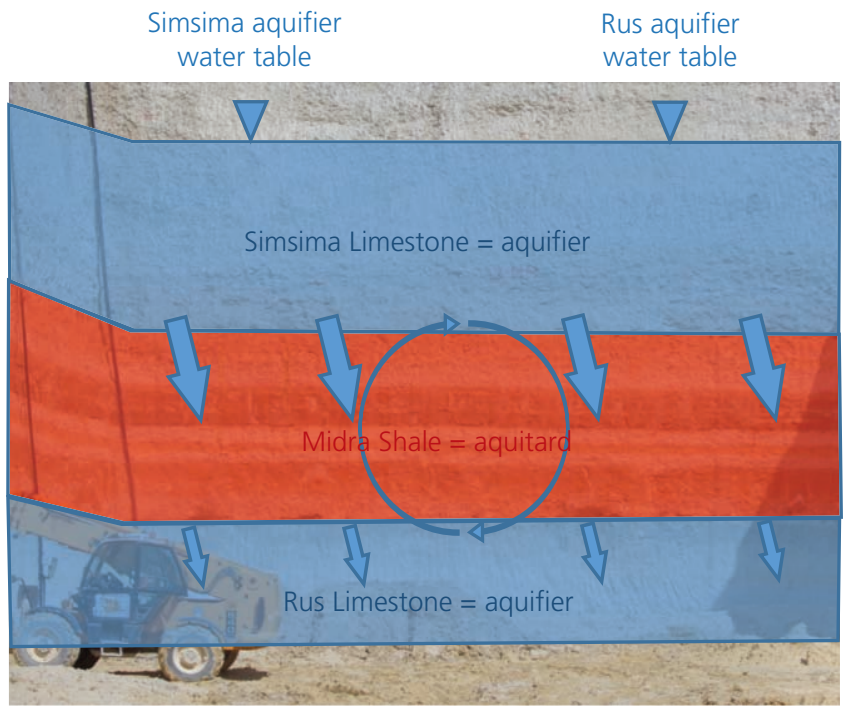

Figure 1. Illustration of the typical hydrogeological conditions in Doha

There are few observations on the information shown in Figure 1.

- The Simsima and Rus aquifer water tables are generally encountered at similar elevations, which suggests a degree of hydraulic conductivity between the two aquifers.

- When performing deep open excavations with deep wells dewatering, the interface between the Midra Shale and the Simsima Limestone is generally subject to increased groundwater flow. To a lesser extent, this is also true at the boundary between the Midra Shale and the Rus Formation.

The effectiveness of the Midra Shale Formation to act locally as an aquitard depends on the presence and thickness of its shale layers, their clay content and the characteristics of the nonhorizontal discontinuities.

The Rus Formation is exposed at the surface and recharged in Saudi Arabia. Simsima Limestone is not considered an aquifer at a regional scale. The potentiometric surfaces in the Simsima Limestone and Rus Formations are typically found at similar elevations, suggesting regional hydraulic conductivity of the two aquifers through the Midra Shale Formation.

The permeability of the Doha rock masses is governed by their discontinuities, karst and weathering features, resulting in wide ranges of rock mass permeabilities within short distances. The primary rock porosity permeability is typically of lesser significance.

The rock mass permeability of the limestones is furthermore influenced by their dolomitisation degree. Non-dolomitic limestones of the Simsima Limestone Formation have been found to be related to significantly increased groundwater inflows compared to the dolomitic limestones.
Rock mass permeability in the Rus Limestone Formation has been observed to be generally lower than that of the Simsima Limestone Formation. This is attributed to the Rus Formation Limestone being chalky, which contributes to a lower permeability, and to the presence of claystone layers.

The vertical permeability of the rock mass in Doha is significantly smaller than the horizontal permeability because of the following.

- The layers are typically horizontal to subhorizontal, and low-permeability layers such as shales and mudstones are present.

- The main discontinuity set comprises undulating subhorizontal discontinuities.

- Other discontinuity sets comprise near-vertical features but of low persistency.

The fluxes through the Midra Shale Formation are through discontinuities, through the limestone layers when shale layers are absent or very thin and through man-made water pathways such as open boreholes and wells.

The groundwater regime and mainly the Simsima Limestone Formation groundwater are affected within the urban area by various factors

- artificial recharge due to irrigation, utility leakage and leakage through man-made surface water features such as the artificial lake in the Aspire Zone

- temporary dewatering to enable underground construction and permanent dewatering to protect existing basements

- obstructions to groundwater flow such as large underground structures (metro stations, piled walls etc.) and basements.

Excluding anthropogenic influences and short-term effects resulting from heavy rainfalls, the groundwater gradients in both the Simsima and the Rus aquifers are expected to be low because of the following.

- The topography is gentle.

- There are no natural permanent surface water accumulations or streams.

- The Simsima aquifer is unconfined.

- The two aquifers are hydraulically connected.

- There are no significant inclined features such as faults to disrupt the hydrogeological regime.

Horizontal water circulation is increased at the interface of both the Simsima Limestone and Rus Limestone Formations with the Midra Shale Formation due to the high difference in permeability of the adjacent rock formations.

\section{Geotechnical hazards}

This section presents a descriptive list of the main geotechnical hazards encountered on projects in Doha. 
Weathered Simsima Limestone features (cavities, surface depressions and sinkholes)

Karstification processes in Doha through the dissolution of limestone and gypsum from acidic groundwater have resulted in the frequent presence of cavities at various scales and depths and the presence of surface expressions such as highly weathered features, sinkholes and depressions. The scale of depressions in plan ranges from several metres to several hundred metres. Highly weathered Simsima Limestone features that originate at the surface are commonly bowl or pipe shaped. Smaller features could be missed in borehole investigations and are more likely to be identified through geophysical surveys. Weaker layers leading to excessive deformations increase the risk of damages to buildings and the risk of collapse.

Underground cavities are zones of structural weakness and are less able to support overlying rock (Williams, 2009). Therefore, their identification is crucial for geotechnical design. Small-scale cavities (up to several metres) can be present in both the Simsima Limestone and Rus Limestone Formations due to the dissolution of limestone from acidic groundwater. Such features can also grow upwards over time through a progressing failure and collapse mechanism. The surface expressions of such collapsed karst caves are sinkholes and a karst surface pockmarked with hollows and depressions (Williams, 2009). Larger-scale cavities are developed in Doha in the Rus Gypsum layers, as gypsum is more susceptible to dissolution from flowing water than limestone.

\section{Karstic zones}

Examples of interconnected karstic features are solution channels and small cavities. The karstic zones can be of considerable scale. Infill can be either present in situ or transported. Karstic zones are associated with increased groundwater inflows and rock mass structural weakness. These can lead to localised instability, lack of support for foundations and ground movement. The resulting hydraulic network is complex, and it is difficult to investigate and assess with conventional site investigation techniques.

\section{Karstic connectivity and high groundwater inflows}

Karstic zones have the potential for extended water circulation due to their connectivity to wider karst networks and in extreme cases to the sea. Furthermore, water inflows have been found to be higher in non-dolomitic limestones, as they are more susceptible to karstification than dolomitic limestones. In extreme cases, high groundwater inflows can be temporarily uncontrollable (for example, when a high groundwater flow velocity karstic network is suddenly connected to underground excavation works), and the flow can, in some cases, exceed the discharge capacity/ permit allowance.

Such occurrences have been successfully managed when the features where identified during the site investigation, and preconstruction grouting was used to reduce the risk of high groundwater inflows.

\section{Excessive ground movement due to the presence of gypsiferous material}

The gypsiferous material of the Rus Gypsum Formation has the potential for extended dissolution due to the high solubility of the gypsum material. This process can result in large-scale cavities with the potential for collapse and ground movements in the overlying materials. This is a risk for buildings and foundations supported above weak material. It is recommended to take these hazards into consideration during site investigations, design and construction to mitigate and where possible prevent any risks.

\section{Simsima Limestone Formation proposed geotechnical classification system}

\section{Geotechnical characteristics of the Simsima Limestone Formation}

The Simsima Limestone Formation is the shallowest rock layer in Doha, and as such, it affects the majority of underground construction activities.

The formation is poorly bedded, fine to medium grained and comprises older limestone fragments of several centimetres in dimensions within a newer chalky matrix. As discussed by Fourniadis (2010), it is irregularly dolomitised, light grey to brown and crystalline, with local intercalations of chert and gray attapulgite (a type of swelling clay). The unit has a tendency for dissolution that is significantly enhanced in the newer, chalky matrix. The matrix has been variably affected by cementation and diagenetic processes resulting in variable engineering properties. Small-scale non-interconnected vugs with varying spatial frequency are common.

Following the deposition of the Simsima Limestone in a shallow marine environment, the sea levels dropped, exposing the rocks to weathering during the Oligocene. Wet climatic conditions during the Pleistocene initiated the development of karst dissolution features of various sizes (from centimetres to tens of metres long) (Sadiq and Nasir, 2002). These karst features are often infilled by variably cemented fine-grained material.

Fourniadis (2010) also discussed how the weathering profile of the Simsima Limestone is often complex with highly weathered rock alternating with unaltered rock or cavities secondarily infilled with weakly cemented carbonate rocks encountered in arid environments. Such a weathering profile is therefore in contrast with typical profiles of 'weathered' over 'unweathered' rock encountered in more humid environments. The Simsima Limestone has been shown to be a variable material with the potential for significant lateral and vertical differences in properties even over short distances.

\section{Proposed classification system}

The proposed classification system suggests the division of the Simsima Limestone Formation in four units of differing fracturing/weathering degrees based on borehole cores assessment 
as shown in Table 3. In order to have a practical unit differentiation, which is easy to apply to site investigation records, the proposed definition of the range of each unit is based on the rock quality designation (RQD) classification as proposed by Deere and Deere (1988), the rock mass weathering classification according to International Society of Rock Mechanics and EN ISO 14689 , total core recovery (TCR) values and number and values of performed standard penetration tests (SPTs).

The differing fracturing/weathering degrees of the Simsima Limestone Formation are a result of both mechanical (fracturing) and chemical (dissolution) secondary weathering processes and the presence of bedding weakness planes. This is illustrated in Table 4 .

Identifying the rock weathering state and examining the presence of a continuous framework of fresh or discoloured rock is critical in differentiating between the different units of the proposed classification system. The following are noted.

- The colour of the matrix and the older limestone fragments in the Simsima Limestone Formation in Doha serves as a strong indication of their weathering state. Material of green or red colour is expected to be highly weathered and disintegrated to silt(stone)/clay(stone).
- The tendency for weathering and disintegration is increased in chalky material and decreased in dolomitised/microcrystalline material.

- In core runs of low total core recovery where the weathered matrix might have been washed away during drilling, the angularity of the recovered rock parts may provide a useful insight in the weathering pattern as subangular to subrounded rock parts are typically related to chemically weathered material, while angular rock fragments typically result from mechanical fracturing or drilling disturbance (Figure 2).

- Near-vertical subangular to subrounded undulating interfaces between chemically weathered and unweathered rock observed in the recovered cores indicate limestone dissolution along rainwater infiltration paths and could be associated with a fresh rock continuous framework (Figure 3). Such features initiate near the surface and can be several metres deep. The following characteristics are also indications of 'infiltration weathering'. They may assist to differentiate this type from other weathering patterns but should be complemented by additional investigation data where possible

- presence of completely non-weathered core pieces in between highly weathered rock (Figure 4) (in contrast, the

Unit Definition (any of the following conditions)

HWSL $^{a}$ Highly weathered Simsima Limestone

MWSL Moderately weathered Simsima Limestone

SWSL Slightly weathered Simsima Limestone

\section{SL Simsima Limestone}

1a: $R Q D=0 \%$

$1 \mathrm{~b}: 0<\mathrm{RQD} \leq 25 \%$, and $\geq 50 \%$ of the rock material is decomposed and/or disintegrated to soil; fresh or discoloured rock is present either as a discontinuous framework or as core stones 1c: $T C R<50 \%{ }^{b}$

$1 \mathrm{~d}$ : Two or more SPT tests of $N<50$ in a single core run that is $<1.5 \mathrm{~m}$ (based on the assumption that an SPT test is performed after a low TCR core run or presence of very weak material) $)^{\mathrm{b}, \mathrm{c}}$

2a: $0<R Q D \leq 25 \%$, and $<50 \%$ of the rock material is decomposed and/or disintegrated to soil. Fresh or discoloured rock is present either as a continuous framework or as core stones $2 \mathrm{~b}: \mathrm{RQD}=26-50 \%$, and $>30 \%$ of the rock material is decomposed and/or disintegrated to soil. Fresh or discoloured rock is present either as a discontinuous framework or as core stones 3a: RQD $=26-50 \%$, and $<30 \%$ of the rock material is decomposed and/or disintegrated to soil; fresh or discoloured rock is present either as a continuous framework or as core stones $3 \mathrm{~b}: \mathrm{RQD}>50 \%$, and discolouration indicates weathering of rock matrix and discontinuity surfaces; all the rock matrices may be discoloured by weathering and may be somewhat weaker externally than in its fresh condition

4: RQD $>50 \%$ and no or slight discoloration of rock matrix indicating fresh rock

\footnotetext{
a The description proposed for the HWSL material has evolved over the course of ground investigation campaigns as close collaboration with recurring site investigation contractors enabled improving the drilling quality. The authors have proposed several criteria so that HWSL may be conservatively identified and logged, irrespective of the drilling quality achieved on site

${ }^{b}$ If condition 1c or $1 d$ is satisfied, the material is classified as HWSL regardless of the RQD value and the percentage of the rock material that is decomposed and/or disintegrated to soil

c This condition is empirical and based on the assumption that SPTs are performed following low core recovery and/or weak conditions as interpreted by the driller and the geologist on site during drilling. It is difficult to allocate exact numbers to this part of the condition, as the assessment is highly reliant on judgement based on information available on site
} 
HWSL (1a)

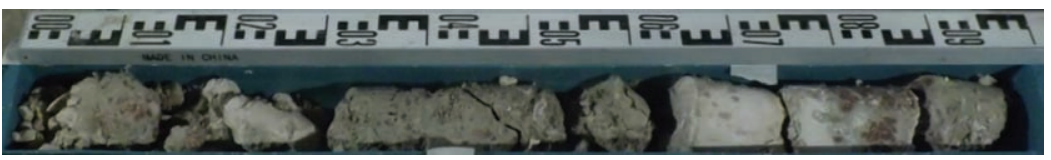

$\operatorname{MWSL}\left(2 a^{b}\right)$

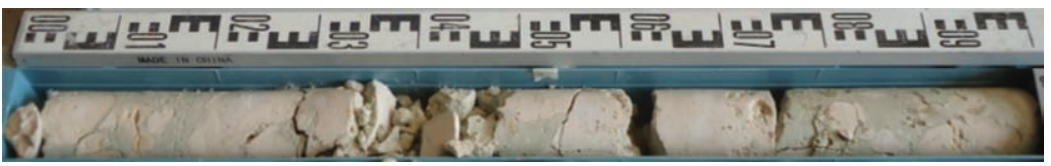

SWSL (3a)

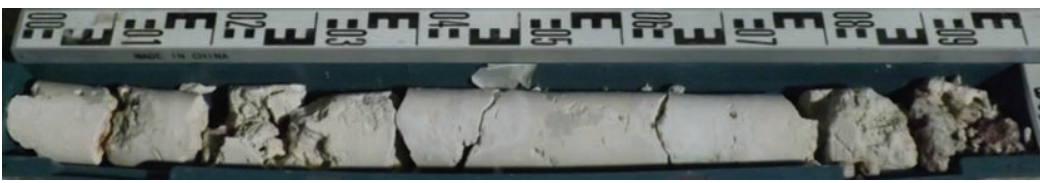

SL (4)

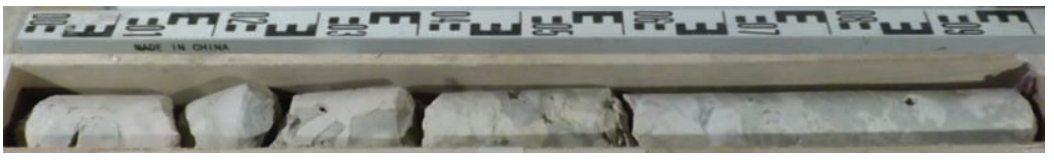

a Satisfied condition according to Table 3

b The MWSL core in Table 4 seems to consist mostly of full-diameter solid rock pieces that can be assigned RQD values. In reality, it comprises mostly rock pieces within a weathered soil-like matrix. There is only one solid rock core piece long enough to be given an RQD value; thus, the overall RQD allocated to the length of core shown is $11 \%$. In addition, less than $50 \%$ of the rock material is decomposed and/or disintegrated to soil. Thus, it is classified as MWSL according to condition 2a of Table 3

Table 4. Indicative Simsima Limestone Formation core photographs per unit of the proposed classification system presented in Table 3

cobbles and boulders within highly weathered masses are typically partly affected by weathering (Figure 5))

- small-scale (centimetres to decimetres) alterations between weathered and non-weathered rock along several metres of core as opposed to thick concentrations of highly weathered material.

- weathering degree that generally decreases downwards (other weathering processes such as weathering along fractures may result in unweathered rock above weathered rock).

Limitations and applicability of the proposed geotechnical classification system

The differentiation of the Simsima Limestone Formation into four distinct weathering units is not applicable for small-scale investigations due to the small number of available samples that would not allow assigning characteristic geotechnical parameters

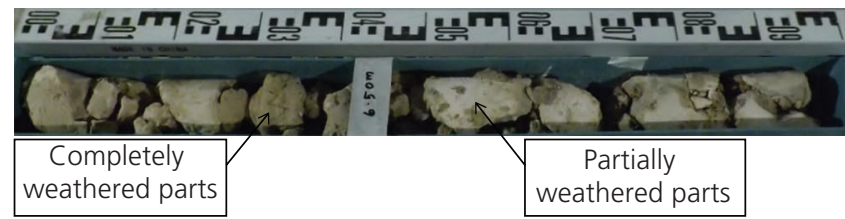

Figure 2. Core photograph of chemically weathered Simsima Limestone (1 m long) for each unit. For such investigations, the number of units can be decreased by unifying some of the units in Table 3, according to the project's design objectives, in order to be able to process statistically the test results.

- Slightly weathered Simsima Limestone (SWSL) could be combined with Simsima Limestone in a single unit as the most competent unit of Simsima Limestone for most engineering purposes.

- It is suggested that HWSL forms a separate unit for the majority of construction programmes, as it poses distinct characteristics which usually influence the choice of geotechnical solutions applied to it. The identification of HWSL also provides useful information with regard to the presence of geotechnical hazards such as karstic zones, chemical weathering features and ground movements.

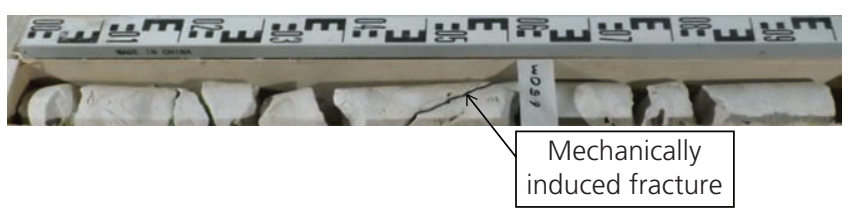

Figure 3. Core photograph of mechanically weathered Simsima Limestone (1 m long) 
Geology and geotechnical evaluation of

Doha rock formations

Karagkounis, Latapie, Sayers and Mulinti

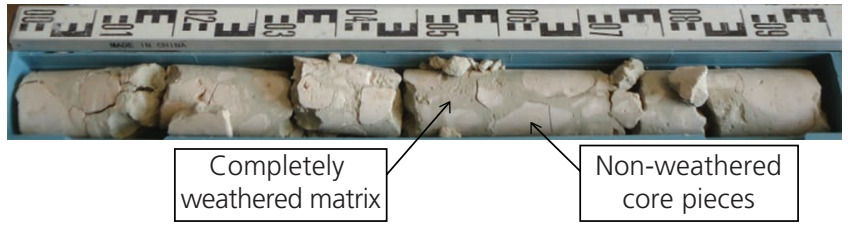

Figure 4. Non-weathered core pieces in between highly weathered rock (1 $\mathrm{m}$ long)

- Determination of the strength characteristics of HWSL through laboratory testing is challenging due to the scarce availability of samples suitable for unconfined compressive strength (UCS) tests. Furthermore, the applicability of UCS test results in determining the strength values of HWSL is problematic; as in most cases, the samples are parts of cobles or boulders within a weaker matrix with high clay/silt content and are therefore not representative of the unit characteristics. Triaxial tests could be used to test the weaker material that mostly comprises HWSL units.

\section{Applicability of RQD for the geotechnical classification of} the Simsima Limestone

RQD and weathering are the two parameters considered for the assessment of Simsima Limestone rock mass quality according to the proposed classification system.

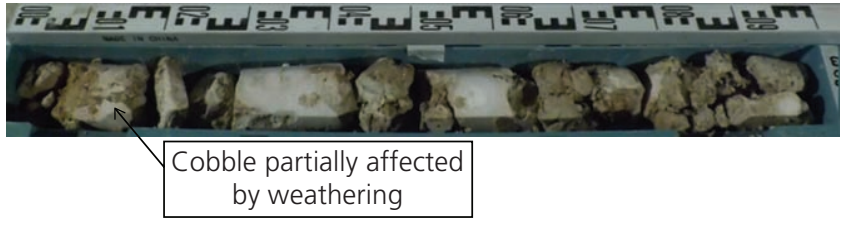

Figure 5. Core photograph of cobbles and boulders within highly weathered masses partly affected by weathering ( $1 \mathrm{~m}$ long)

Following the analysis by Palmstrom (2005), the discontinuity orientation in Doha is such that the RQD values derived from vertical boreholes are considered representative of the fracturing state of the rock mass. The bedding planes and the dominant discontinuity set are undulating horizontal to subhorizontal.

The discontinuities of the remaining near-vertical discontinuity sets being subparallel to the vertical investigation boreholes might be missed in the borehole cores. However, the significance of these discontinuity sets is in most cases limited due to their low persistence (typically $1 \mathrm{~m}$ ).

\section{Geotechnical parameters}

According to the authors' experience with geotechnical works and investigations in Doha that have covered a significant part of the city, typical ranges of geotechnical parameters per geotechnical unit are presented in this section that are considered representative

\begin{tabular}{|c|c|c|c|c|c|c|c|c|}
\hline \multirow[t]{3}{*}{ Rock unit } & \multicolumn{6}{|c|}{ Parameter } & \multirow{2}{*}{\multicolumn{2}{|c|}{$\begin{array}{l}\text { Equivalent Mohr-Coulomb } \\
\text { parameters }\end{array}$}} \\
\hline & \multirow{2}{*}{$\begin{array}{l}\text { Unit weight, } \\
\gamma: \mathrm{kN} / \mathrm{m}^{3}\end{array}$} & \multirow{2}{*}{$\begin{array}{l}\text { UCS: } \\
\text { MPa }\end{array}$} & \multirow{2}{*}{$\begin{array}{c}\text { Rock mass } \\
\text { Young's modulus, } \\
E_{\mathrm{RM}}: \mathrm{MPa}\end{array}$} & \multirow{2}{*}{$\begin{array}{l}\text { Poisson's } \\
\text { ratio, } v\end{array}$} & \multirow{2}{*}{$\begin{array}{l}\text { Coefficient } \\
\text { or at-rest } \\
\text { pressure, } K_{0}\end{array}$} & \multirow{2}{*}{$\begin{array}{c}\text { Permeability, } \\
k: \mathrm{m} / \mathrm{s}\end{array}$} & & \\
\hline & & & & & & & $\begin{array}{l}\text { Angle of internal } \\
\text { friction, } \phi:^{\circ}\end{array}$ & $\begin{array}{c}\text { Cohesion, } C^{\prime}: \\
\text { kPa }\end{array}$ \\
\hline HWSL & $19-21$ & $-^{a}$ & $125-275$ & $0 \cdot 19-0 \cdot 24$ & $0.7-0.9$ & $\begin{array}{l}3 \cdot 1 \times 10^{-6}- \\
3 \cdot 0 \times 10^{-4}\end{array}$ & $21-33$ & 33-105 \\
\hline MWSL & $20-25$ & $5-17$ & $250-1250$ & $0 \cdot 16-0.27$ & $0.7-0.9$ & $\begin{array}{l}3 \cdot 1 \times 10^{-7}- \\
4.0 \times 10^{-4}\end{array}$ & $33-47$ & $60-210$ \\
\hline SWSL & $21-24$ & $6-20$ & $1000-4650$ & $0 \cdot 15-0 \cdot 29$ & $0.7-0.9$ & $\begin{array}{l}1.6 \times 10^{-6}- \\
1.7 \times 10^{-4}\end{array}$ & $38-50$ & $70-310$ \\
\hline SL & $20-24$ & $9-23$ & $1500-7150$ & $0 \cdot 18-0 \cdot 27$ & $0.7-0.9$ & $\begin{array}{l}1.6 \times 10^{-7}- \\
3.0 \times 10^{-4}\end{array}$ & $42-53$ & $100-440$ \\
\hline MS & $18-23$ & $5-17$ & $1000-5500$ & $0 \cdot 17-0 \cdot 32$ & $0.7-0.9$ & $\begin{array}{l}9.6 \times 10^{-9}- \\
6.7 \times 10^{-5}\end{array}$ & $33-46$ & 40-345 \\
\hline RFL & $18-22$ & $4-9$ & 1000-2000 & $0.23-0.35$ & $0.7-0.9$ & $\begin{array}{l}5.7 \times 10^{-8}- \\
4.9 \times 10^{-5}\end{array}$ & $30-38$ & $30-200$ \\
\hline RUS GYP & $20-22$ & $5-17$ & 2000-10500 & $0 \cdot 20-0 \cdot 35$ & $0.7-0.9$ & $\begin{array}{l}6 \cdot 1 \times 10^{-8}- \\
3 \cdot 2 \times 10^{-5}\end{array}$ & $35-48$ & $40-400$ \\
\hline
\end{tabular}

a The HWSL unit encountered was generally too weak to enable the recovery of samples large enough to be tested with a UCS apparatus SL, Simsima Limestone; RFL, Rus Formation Limestone; HWSL, highly weathered Simsima Limestone; MWSL, moderately weathered Simsima Limestone; SWSL, slightly weathered Simsima Limestone; MS, Midra Shale; RUS GYP, Rus Gypsum

Table 5. Summary of Doha characteristic ground parameters per geotechnical unit 


\begin{tabular}{lcc}
\hline \multirow{2}{*}{ Unit } & \multicolumn{2}{c}{$\mathrm{RMR}_{89}^{\prime}$ range } \\
\cline { 2 - 3 } & Minimum & Maximum \\
\hline HWSL & 10 & 30 \\
MWSL & 25 & 40 \\
SWSL & 30 & 50 \\
SL & 45 & 70 \\
MS & 40 & 65 \\
RFL & 25 & 55 \\
RUS GYP & 40 & 60
\end{tabular}

Table 6. Summary of RMR (based on the study by Bieniawski (1989)) encountered in Doha

of the local ground conditions. A brief description of the parameters derivation procedure is provided and the ranges of parameters are summarised in Tables 5 and 6 .

\section{Rock shear strength}

Equivalent Mohr-Coulomb shear strength parameters are proposed as they allow the use of the most commonly available failure envelope in modern geotechnical design software. Based on the authors' experience, the shear strength behaviour of the rock units present in Doha are typically controlled by the rock mass shear strength rather than discontinuities, and as such, the use of the Mohr-Coulomb constitutive model is deemed reasonable for such rock units. The shear strength parameters were derived predominantly following the Hoek-Brown failure criterion presented in the study by Hoek et al. (2002). The Doha rock units are typically confined to the lower end of the rock competency scale, and the modifications proposed by Carter et al. (2008) to the Hoek-Brown criterion for such rocks may be implemented to refine further the shear strength parameters that may be derived for rocks in Doha. The selection of an adequate maximum confining stress was essential when deriving equivalent Mohr-Coulomb parameters; this is further discussed by Latapie and Lochaden (2016).

A series of rock characterisation parameters such as rock mass rating (RMR), geological strength index (GSI), RQD, the rock mass factor $j$, the material constant $m_{i}$ and the disturbance factor $D$ were obtained from the borehole logs and supervision records in order to support the derivation of shear strength parameters for rock units, which is mainly based on UCS values. The RMR values used to derive the shear strength parameters followed the Bieniawski classification from 1989 with the modifications recommended by Hoek et al. (1995) with regard to the groundwater rating and the rating adjustment for discontinuities orientations. Further details of this process are provided in the next section.

\section{Correlations between UCS and point load index $\left(I_{\mathrm{s}, 50}\right)$}

The intact strength of rock can be assessed by both UCS and point load tests. However, the UCS test results are more representative of the unit strength because they test a larger sample and have been used widely in correlations to determine other geotechnical parameters. The point load test results are not directly comparable to the UCS test results, and therefore, a conversion factor needs to be adopted. Most published relationships that correlate point load indexes to UCS values recommend coefficients on the order of 20-22. According to Johnston (1991), point load index-to-UCS correlation factors of 7 and 10 are recommended for weak rocks with average UCS values of 2 and $10 \mathrm{MPa}$, respectively. A sensitivity analysis has been carried out in deciding the correlation ratio to determine its effect on the average UCS value derived from point load indexes. It has been found that using a ratio of 7-10 between UCS and point load values is appropriate for the weak rocks in Doha.

As a consequence, the point load index test results were correlated as equivalent UCS values using the following relationship

\section{1. $\mathrm{UCS}=I_{\mathrm{s}, 50} \times(7-10)$}

\section{Rock stiffness}

The rock mass stiffness was predominantly derived using the results of laboratory tests and published empirical relationships using the following parameters: $E_{\mathrm{i}}$, RMR, UCS, GSI and $D$. The methods proposed by Hoek and Brown (2002), Hoek and Diederichs (2006) and Galera et al. (2005) were used. The resulting rock mass stiffnesses were then validated against in situ pressuremeter test results.

\section{Performed tests}

The above ranges of parameters are indicative, and they cannot replace site-specific geotechnical investigation, which is always necessary to capture the local geotechnical conditions for each structure/project. The laboratory and in situ tests performed during the ground investigations used to produce this paper are listed, with their corresponding standard, in Table 7.

\section{Applicability of rock classification methods RMR and GSI}

\section{Rock mass rating}

The ground conditions in Doha are that of weak rocks in rock masses of varying fracturing and weathering degrees. Such conditions are taken into account in the RMR classification system proposed by Bieniawski (1989). As presented in previous sections of this paper, the expected range of RMR values is between 10 and 60 - that is, very poor to fair rock quality according to Bieniawski (1989).

Hoek et al. (1995) suggested that the RMR system would not work for very weak rock masses. Nevertheless, according to Bieniawski (2011), 'RMR continues to be used successfully even for "very poor rock masses", Class V when RMR $<20$, when the input data are properly determined'. Furthermore, Bieniawski (2011: p. 4) states that 
Specific gravity

Bulk density

Moisture content

Liquid and plastic limits and plasticity index

Particle size analysis

Hydrometer

Unconsolidated - undrained triaxial

Oedometer (one-dimensional) consolidation

Compaction

Shear strength

Moisture content

Porosity

Bulk density

Intact dry density

Unconfined compressive strength with measurement of Young's modulus and Poisson's ratio

Point load strength

Cerchar

Slake durability

Direct shear strength

Rock swelling pressure

SPT

In situ physical testing

Pressuremeter

Variable head permeability

Packer permeability

Pumping

MASW

In situ geophysical testing

Cross-hole seismic

Downhole seismic

\section{Laboratory soil testing}

$$
\begin{aligned}
& \text { BS 1377:1990 } \\
& \text { (BSI, 1990) }
\end{aligned}
$$

Part 2, test 8

Part 2, test 7

Part 2, test 3.2

Part 2, tests 4.3 or 4.5

and 5

Part 2, tests 9.2 and 9.4

or 9.5

Part 2

Part 7, test 8

Part 5, test 3

Part 4, test 3

Part 7, test 4
Brown (1981)

ASTM D 7012 (ASTM, 2014a)

Franklin (1985)

ASTM D 7625 (ASTM, 2010)

ASTM D 4644 (ASTM, 2016)

ASTM D 5607 (ASTM, 2008)

Brown (1981)

\section{BS 1377}

BS EN ISO 22476-3 (BSI, 2005); minimum of two unload-reload cycles, a maximum pressure capacity of $20 \mathrm{MPa}$ is anticipated

Determination of permeability and measurements according to BS 5930 (BSI, 2015)

Determination of permeability and measurements according to BS 5930 (BSI, 2015)

BS ISO 14686:2003 (BSI, 2003) BS EN ISO 22282-

4:2012 (BSI, 2012)

Park et al. $(2000,2002)$

ASTM D 4428 (ASTM, 2014b)

ASTM D 7400 (ASTM, 2014c)

Table 7. Performed tests and their reference/standard

'the myth that ... for weak rock masses, the RMR classification is not applicable for the lowest class of ratings ... stems from a number of misconceptions arising when rock mass classifications are treated as a "black-box" or "cook book" expecting ready "recipes" for all design situations. In a publication in 1991, I cautioned engineers and geologists that weak rock masses do require special attention for careful geotechnical characterization because the accuracy of RMR, depending on expertise, maybe to within 2-3 rating points (the same applies to other classifications). But this does not mean that the RMR system cannot be applied to assess very poor rock masses. After all, we have numerous case histories on record with RMR $=$ zero to $3^{\prime}$.

Further to the earlier statement, the authors' experience in Doha has shown that the RMR classification values based on borehole cores, slope faces and tunnel faces lead to realistic parameters for 
the calculation of stand-up time, structural loads and primary support systems.

\section{Geological strength index}

According to Hoek et al. (1998: p. 151), 'the GSI provides a system for estimating the reduction in rock mass strength for different geological conditions as identified by field observations'. It 'provides a practical basis for describing a wide range of rock mass types, with diversified rock structure ranging from very tightly interlocked strong rock fragments to heavily crushed rock masses'.

Furthermore, according to Marinos et al. (2005: p. 59), 'The GSI classification system is based upon the assumption that the rock mass contains a sufficient number of "randomly" oriented discontinuities such that it behaves as an isotropic mass. In other words, the behaviour of the rock mass is independent of the direction of the applied loads. Therefore, it is clear that the GSI system should not be applied to those rock masses in which there is a clearly defined dominant structural orientation'.

The characteristics of the Doha rock masses discussed in the present paper (Simsima, Midra Shale and Rus) do not comply with the requirements mentioned earlier for GSI to be applicable, as

a there is a dominant subhorizontal discontinuity set

- discontinuities belonging to other discontinuity sets are not as frequent and persistent as required for an isotropic-behaving mass to be formed.

Therefore, this means that the GSI classification system is not directly applicable for the Doha ground conditions. As a consequence, this classification system ought to be used with caution, as an indicative characterisation rather than an absolute tool.

The GSI classification system has been utilised in several projects in Doha to communicate successively the rock quality properties observed on open excavations. The authors' methodology included back analysis of open excavation and pragmatic use of the available GSI classification system. The GSI values were generally used as a communication tool of the geotechnical engineer's perception of the rock mass quality, refraining from linking design calculations to the literal application of the GSI approach.

The GSI values have also been used as an input to the Hoek-Brown criterion in several designs. The GSI in such cases has been derived through the following correlation formula with the derived $\mathrm{RMR}_{89}^{\prime}$ values as suggested by the Bieniawski (1989) classification, which includes the adjustments for groundwater rating and joint orientation.

$$
\mathrm{GSI}=\mathrm{RMR}_{89}^{\prime}-5
$$

The GSI values obtained with this method have been proven suitable of the in situ rock material when implemented on site.

The system developed, although not perfect from a geological viewpoint, enabled the successful implementation of the authors' temporary works designs in safe conditions. The current limitation of this approach is that there is currently no means of verifying the subjective rock mass quality estimations, and thus, the GSI values obtained for Doha rocks are arbitrary. The authors suggest that further research and work be carried out on this subject in order to propose a modification to the existing GSI classification system to make it suitable to the rock formations present in Doha.

For the classification of rock masses in Doha, the role of the heterogeneity of the rock mass should also be considered, in particular in the Midra Shale and Rus Formations that include interlayered materials of differing weathering and strength characteristics. The scale of these zones should be considered compared to the scale of the project. If the different zones are small compared to the project/structure, one RMR/GSI value may be considered for the whole rock mass, whereas in a different case, a different value should be considered for each zone.

\section{Ground investigation techniques}

The optimal ground investigation techniques discussed in this section have also considered the presently commonly available equipment in Doha and common issues that have been faced during site investigations in the area.

The stratigraphy in Doha is largely consistent. The three basic largely subhorizontal formations (Simsima, Midra Shale and Rus) are present throughout the city, and there is a lack of tectonic features such as faults and thrusts that could disrupt the stratigraphical continuity (with the exception of collapse features). The variability of the ground conditions is mostly attributed to variations in the thickness and lithology of the formations and to the effect of diagenetic and secondary processes such as karstification and weathering. The main challenge for ground investigation programmes is to predict the spatial distribution of karst and weathering features in a scale relative to engineering works.

\section{Drilling techniques}

In the Doha ground conditions, triple-tube drilling has been found to produce high core recoveries with limited disturbance. The performance of two different triple-tube drilling techniques is discussed in this section: triple tube including inner plastic liner and triple tube including inner split barrel.

According to the authors' experience in Doha, both drilling techniques can provide a drilling quality appropriate for engineering applications. Nevertheless, the drilling quality has been observed to be more consistent when the split inner barrel equipment is employed. The statistical analysis of the available data showed that the 'split barrel' technique on average outperformed the 'plastic liner' technique in terms of core 
recovery parameters (TCR, solid core recovery (SCR) and RQD) in all three formations. Nevertheless, there have been sites where the plastic liner technique provided better results which proves the importance of the competence of the drilling personnel and in particular with this technique.

The advantages and disadvantages of each technique for the ground conditions in Doha are summarised in Tables 8 and 9.

Different core diameter drilling is typically performed in order to conduct pressuremeter tests subsequently. The respective core runs are typically $1.5 \mathrm{~m}$ long, and the cores produced have a $56 \mathrm{~mm}$ diameter, when using $\mathrm{N}_{\mathrm{x}}$ drill core size. Due to the lower diameter of the cores and the single tube method, the cores retrieved with this method generally exhibit lower core recovery parameters, which is attributed to increased drilling disturbance. It is suggested that this effect is taken into account when attempting to identify disturbed ground conditions. Specifying larger drilling diameters when performing pressuremeter testing on site would enable achieving higher core recovery for such sections of the borehole. Furthermore, correlations should be made with other available investigation data and the understanding of the local ground regime.

\section{Borehole logging}

The characteristics of the rock masses encountered in Doha lead to challenges for the borehole logging process as discussed in the following.

Differentiating the natural fractures from drilling-induced fractures has been observed to be challenging, in particular in the Midra Shale Formation, where bedding planes can be separated due to drilling disturbance and appear as fractures. In addition, differences have been observed in the average values provided by different subcontractors operating in Doha. Detailed specifications and early discussions on a common approach are suggested for consistency along a project.
- Cores can be examined on site. Drilling and in situ tests can be adjusted accordingly and core recovery measurements conducted as soon as the core is recovered.

- The maximum performance advantage in terms of TCR and core disturbance of the 'split barrel' compared to the 'plastic liner' technique was recorded in fractured bimodal Simsima.
- Core handling site work is increased compared to the 'plastic liner' technique. The cores have to be extracted from the barrel, wrapped with cling film and then placed in the core boxes. This processes increases core disturbance and site work.

Table 8. Advantages and disadvantages of the triple tube including split inner barrel technique

- Procedures on site are easier once the barrel is retrieved. The plastic liners containing the core are tapped and placed in core boxes.

- This technique is considered more effective in soil conditions in terms of core recovery and minimising core disturbance.

- Transportation disturbance is minimised because the cores are contained in the liner.
- Plastic liners can melt or be stuck while drilling, in particular in bimodal Simsima fractured conditions, which leads to drilling-induced disturbance and delays. Such issues can be minimised with appropriate drilling adjustments.

- Cores cannot be examined on site in detail, as the visibility through the plastic liners is limited. This leads to lack of information on ground conditions and drilling performance on site and does not allow for informed adjustments of the drilling procedures and investigation works schedule. Borehole logging on site is only possible if the liner is cut, which cancels most of the method's advantages.

- It was noted that the drilling personnel in Doha is generally inexperienced with the plastic liner method (2014-2015) which is believed to have affected the observed drilling quality.

Table 9. Advantages and disadvantages of the triple tube, including inner plastic liner technique 
HWSL matrix that is nevertheless able to form full-diameter cores is frequently mistakenly classified as rock core. Consequently, unrealistic high SCR and RQD values can be mistakenly assigned to such cores when the material that has disintegrated to soil-like structures is incorrectly logged as rock. This can result in a misinterpretation of the actual ground conditions and overoptimistic design. For logging purposes, the colour can be used as a strong indicator of the chemical weathering state of the Simsima Limestone. The chemically weathered material is typically of green or red colour. Nevertheless, as weathering is a gradual process, the cores in the limit between rock and weathered material can be difficult to classify.

\section{Permeability testing}

Permeability testing is an essential part of the characterisation of the rock materials in Doha. In this section, suggested procedures and limitations of the permeability testing techniques commonly used in Doha are discussed. The performances of packer testing against falling head testing are compared, and recommendations for large-scale permeability testing are provided.

\section{Comparison of packer and falling head tests to pumping tests}

Permeability values provided from borehole packer and falling head tests have proven difficult to rely on because the groundwater flow through the rock masses encountered in Doha is controlled by its discontinuities, karstic zones, natural water pipes and so on. The scale of the rock volume tested by packer or falling head test is considerably smaller than the scale of the rock mass features governing the groundwater flow. Therefore, there is a large variability of permeability test results carried within each unit. As a result of the extensive range of permeability values recorded, the subsequent estimation of characteristic values is challenging. This situation has been successfully overcome by undertaking full-scale pump tests on site. Such tests should be performed for a sufficiently long time period to be representative of the groundwater regime. As it affects a much larger volume of rock mass, the pumping test provides a much more representative picture of the groundwater flow regime to be expected at the site.

By the same token, the permeability of each rock unit may not be interpreted from pumping tests, but this deficiency is vastly overcome by a better understanding of the overall rock mass hydraulic conductivity. This is a much-preferred method for Doha rocks, compared with packer and falling head permeability tests.

The main challenges encountered on site related to the performance of packer and falling head tests on Doha rocks are discussed in the following.

\section{PACKER AND FALLING HEAD TESTS IN UNSATURATED GROUND}

Such tests above the groundwater table are considered unreliable and, in accordance with international design standards, should not be used unless the ground subject to the test can be saturated before testing. Nevertheless, the ground saturation degree can be affected by the drilling water, and thus, the test results might be more reliable depending on

- the duration of drilling

- the water level in the borehole during drilling (favourable conditions for test reliability if it is higher than the test depth)

- the lapsed time between drilling and the permeability tests (favourable if minimised)

- the ground characteristics

\section{CONSIDERATIONS ON SITE WHEN CONDUCTING PACKER TESTS IN THE} DOHA ROCK FORMATIONS

The water level inside the borehole has to be measured before and during the test. Water leakage due to ineffective sealing between the packers and the ground, or due to flow of water through fractures interconnected with the borehole, may be identified by a rise in water level inside the borehole; in such instances, the test results would be higher than the actual ground permeability and the suggested check and, thereafter, corrective measures are

- inspection of the packer equipment for leakage

- adjustment of the test depth in order to avoid the ground conditions that do not allow for effective sealing.

\section{CONSIDERATIONS WHEN CONDUCTING FALLING HEAD TESTS IN THE} DOHA ROCK FORMATIONS

- The water level during falling head tests in rock should preferably be conducted below the casing. If the water level is higher than the casing then it is possible for water to flow between the rock and casing upwards. In such cases, the tested section would be affected, and thus, the test results would be unreliable.

It is noted that falling head and packer tests have been performed in Simsima Limestone in Doha, and there was a very good correlation between the results from the two methods.

It is suggested that the permeability test results are correlated to the specific ground conditions as recorded in the borehole logs and other investigation data. Such an exercise is considered necessary in order to assign permeability values to individual units and to allow for an interpretation of the groundwater flow system. Among the factors to be examined are the presence and characteristics of fractures, the rock weathering state and the natural water head.

\section{Pumping tests}

Pumping tests are of a scale appropriate to estimate hydraulic properties of the aquifer system present in a site such as transmissivity, hydraulic conductivity, storativity and aquifer boundaries.

COMMON FACTORS COMPROMISING THE VALUE OF PUMPING TESTS IN DOHA The common factors compromising the value of pumping tests in Doha are 
- pumping both Simsima and Rus Formations at the same time which does not allow for the hydraulic properties of each aquifer to be derived (such tests may be useful if simulating the actual dewatering conditions but are generally not preferable)

- insufficient testing time

- pump selection by contractors.

\section{IDENTIFICATION OF HIGH WATER FLOW FRACTURES}

High water flow fractures are challenging to identify during the ground investigation phase of a project. Practical experience on projects aided by discussions with specialist dewatering contractors and colleagues from around the industries led to formulating a procedure which is presented in this paragraph. This relates to incorporating the use of flow meters when carrying out a pumping test, ideally as part of the ground investigation campaign. When lowered into a borehole, below the groundwater table, flow meters are able to provide direct measurements of the speed of the groundwater flow. Hence, when arranging an array of flow meters close to a central pumping well, the speed of the groundwater flow can be measured at several locations across the site. Review and interpretation of the retrieved information can help identify areas of higher flow which should be targeted for additional investigation or testing to determine the magnitude of the fracture and their likely impact on the project's dewatering scheme.

\section{Pressuremeter tests}

In situ pressuremeter tests are routinely used in Doha in order to characterise the following rock mass parameters

- rock mass modulus or stiffness; this is done over several consecutive load cycles in order to establish the initial stiffness and unload-reload stiffness of the material

- in situ stress in order to establish the coefficient of at-rest pressures $K_{0}$.

This section provides feedback on the apparatus routinely used in Doha and their ability to establish the parameters mentioned earlier. The most commonly available pressuremeter apparatus in Doha is the pre-drilled pressuremeter system where a destructive borehole is sunk to full depth before the pressuremeter probe is inserted in the borehole, and tests are carried out at various depths. This equipment is normally used for soils and intermediate geomaterials (i.e. extremely weak to very weak rocks). Using this equipment in the in situ rocks of Doha has led to the following observations.

- The apparatus takes a long time (from a few hours to a day) to reach and sustain the pressures required to test the rock mass effectively. This occurs in particular in the least weathered parts of the Simsima Limestone unit, which tends to be the stiffest among the top 30-35 m of stratigraphy.

- The time required for testing leads to less reliable readings and also undermines the ability of the test to measure the on-site condition of the rock as the borehole is left opened a long time, with unsupported wall which have the freedom to 'relax' and dissipate in situ stresses.
- In turn, this leads to unreliable measurements of in situ stresses and the rock mass initial modulus (as the borehole walls have relaxed and lost their in situ stiffness).

- When several unload-reload cycles are carried out during testing, it is usually possible to interpret reliable modulus values.

The findings mentioned earlier have been observed consistently across Doha, through many projects, a vast amount of boreholes and working with several different ground investigation contractors. Hence, the authors feel that the following may be concluded.

- Pre-drilled pressuremeter tests are inadequate to measure reliably in situ stresses in order to define the coefficient of at-rest pressures $K_{0}$.

- Pre-drilled pressuremeter tests are inadequate to measure reliably the initial rock mass modulus for the rock units encountered in Doha.

It is strongly recommended to use more-sophisticated apparatus if initial rock mass stiffness and establishment of in situ stresses are required. For instance, the use of self-boring high-pressure dilatometers would help minimise the disturbance brought to the rock mass before and during testing. However, for this technique to be applicable in Doha, the technical challenge of modifying the drill bit so that it is adequate for the local rock conditions needs to be overcome. Hydrofracture tests are generally more accurate than pressuremeter tests and can have inference on the orientation of any lateral variance in horizontal stress, although complex testing to perform and requires careful interpretation for evaluating the $K_{0}$ value. One of their outputs is an imprint of the rock mass fractures developed during testing which can be interpreted to confirm the direction of the principal stresses and confirm whether the coefficient of at-rest pressures $K_{0}$ is likely to be greater or smaller than unity. Geophysical methods, in conjunction with adequate pressuremeter testing, should also be investigated to assist the assessment. Such method are the most difficult to interpret but are also the only ones that do not disturb the rock mass during testing and attempt to obtain completely undisturbed properties.

\section{Geophysical surveys}

The present section on geophysical surveys is based on findings from multiple years of onshore geophysical investigation and data processing for onshore projects in Doha. The main applications of geophysical surveys for geotechnical projects in Doha are void detection, layer mapping and, less commonly, parameter estimation.

The effectiveness of the different geophysical methods is determined by the local ground conditions. The typical relevant conditions in Doha are as follows.

- The groundwater is of high salinity and the groundwater table level is typically between 1 and $20 \mathrm{~m}$ below ground level (mbgl).

- The ground is predominantly weak rock that may have been affected by weathering, karstification and fracturing processes and is overlain by quaternary deposits. 
In such a setting, the multi-channel analysis of surface wave (MASW) seismic technique has been found to be the most appropriate geophysical investigation method and is consequently the most commonly used in Doha. It is the only geophysical method that is not affected by saline water and can provide information on weak layers that may contain cavities as well as changes in geological materials.

Seismic methods are generally more suited to measure the strength of underlying materials than any other method as they depend on mechanical rock parameters such as density and rock hardness. Surface wave methods such as MASW take advantage of this effect as surface waves (Rayleigh waves) are dominated by the S-wave structure of the underground.

Furthermore, shear wave methods provide ground stiffness properties and can therefore be correlated with borehole methods (cross-hole and downhole) and advanced cross-hole and tomography tests to provide a high degree of confidence in the survey results as the shear wave velocity is collected in situ rather than on core samples that have had the over burden pressure released from them. S-wave values (shear velocity) are used in calculations for allowable load bearing capacity, Poisson's ratio and the elastic modulus of the ground.

An important advantage of S-waves is that they propagate more or less unaffected from water content in contrary to all the other geophysical methods, in that the water table has no effect on the propagation of the signal.

MASW has been in use onshore in Doha since 2002. It is considered effective in void detection with the detectable void sizes increasing with depth. In terms of weathering and fracture profiling, there are limitations in the accuracy of MASW. Nevertheless, if correlated with adjacent borehole data, a reasonable accuracy can be achieved in assessing weathered and fractured zones up to a depth of about $15 \mathrm{mbgl}$ as it has been seen on an extensive number of sites in Doha.

\section{Other geophysical methods}

Ground-penetrating radar (GPR), seismic refraction (SR), SRT, microgravity (MG), electrical resistivity tomography (ERT) and electromagnetics (EM) do not adequately fulfil the needs mentioned earlier.

High-frequency GPR antennae are widely used to map utilities, with lower-frequency antennae being used to map geological variations. However, it does have limitations. GPR will not work in saline water conditions nor in certain clay-rich soils, in particular when they are waterlogged. The reason for this is that in conditions equivalent to a heavily ionised solution the signal produces a current in the ground and no signal is returned. The greater the mineralisation, the greater the loss of signal and hence penetration through the subsurface. GPR also responds to changes in soil type, weathering, density, fracturing, water content as well as many other subsurface features, making reliable identification of the desired objective very difficult.

The ERT method requires setting surface arrays of lengths that may not be possible at sites with obstacles blocking the survey. The length of the array is a function of the penetration of the technique, so enclosed sites cannot always be fully investigated. The method will provide high resolution above the water table, as it also has a limitation where saline water is prevalent in the subsurface. This method is well suited to picking up pockets of materials or cavities due to its 'single-point refractor' acquisition technique rather than layers of geological material. It is excellent at mapping the surface of the water table but can provide very limited information below it due to the blanking effect of the highly conductive water. The very low resistivity reading of the water table masks all the ground material resistivity readings. There would have to be a highly contrasting material present to effect a change in the background resistivity low.

The MG method is slow to acquire due to the precise nature of the acquisition requirement. The systems are highly sensitive, and approximately $20 \%$ of readings are commonly repeated the next day because of environmental vibrations adversely affecting the quality of the readings. This makes large area surveys very expensive. The equipment has temperature limitations which may restrict its use in summer months. Finally, the results do not provide any depth to anomaly and current modelling techniques make the findings subjective.

The SR method cannot detect a low-velocity layer below a higher-velocity layer (as is the case of the Midra Shale) and therefore cannot be considered as a tool for mapping cavities or weak materials that may contain cavities. Added to this, SR data should be acquired in conditions with very little ambient noise. Noise from road traffic, construction sites, airports and so on will mask the input signal and render the data unreliable.

SRT is a relatively new method, and the processing software is still under refinement. It has been shown to be insensitive to abrupt changes in ground conditions, and this raises the issue of what the method may miss geologically such as the change from Simsima to Midra, for example, as well as what it cannot image, such as weak materials that may contain cavities. The SRT method is still therefore limited in its physical capabilities and should be considered only if there is no other viable method to use.

Acoustic (or mechanical) calliper logging can be used in boreholes to investigate fracture geometry in terms of aperture and depth through borehole diameter measurements and thus identify the fractures of high expected groundwater inflow. This information can then be used in the dewatering and grouting design.

\section{MASW site supervision considerations}

The MASW method can provide the ground investigation information discussed earlier if applied diligently on site. The 
following considerations have to be implemented on site for the successful implementation of this method

- generation of low-frequency surface waves with an appropriate source (typically in the range of $80 \mathrm{~kg}$ ) with the use (or not) of an appropriate baseplate

- several test surveys on site to ensure that a known feature (e.g. a pipe) is effectively identified (appropriate adjustments on the site procedure)

all geophones and connections checked for defects such as broken cables and dust in the connection points

- creation of a coherent surface wave ensured on site as this forms the basis of reliable MASW profiling.

Experience in Doha with various geophysical survey companies over the past years has shown that a good quality of MASW surveys is only ensured through

- detailed specifications by an experienced geophysicist

- frequent site works supervision, in particular in the early stages of an investigation

- adjustment of site works according to the assessment of the quality of early works

- the geophysical shear wave interpretation to be preferably conducted by the same team along throughout a project for consistency.

\section{Conclusions}

The geological setting in Doha is relatively simple and consistent with the three basic largely subhorizontal formations (Simsima, Midra Shale and Rus) being present throughout the city and a lack of tectonic features such as faults and thrusts that could disrupt the stratigraphical continuity.

The major ground assessment challenge is to locate and evaluate the risks of ground affected by various degrees of diagenetic, dolomitisation, weathering, karstification and fracturing processes. The resulting hazards are cavities, sinkholes, karstic zones, fractured zones, highly weathered features, collapse features, weak ground and high groundwater inflows. Such features could compromise the stability of the temporary excavations, the structure foundations and the advancement of tunnelling operations.

The hydrogeological units encountered at depths where most civil engineering works are constructed are typically a perched aquifer in the Quaternary deposits, an unconfined aquifer in the Simsima Limestone Formation, an aquitard in the Midra Shale Formation and an underlying partially confined aquifer in the Rus Formation.

A classification system based on RQD values and weathering degree is proposed for the Simsima Limestone Formation to classify the rock in units of differing qualities. The proposed classification system may be applied to both recovered cores and open excavation walls. It is recommended that for most applications, the differentiation between the HWSL and other units of the same formation is maintained due to its distinctively lower strength and stiffness properties. This is because such properties directly impact the design of ground engineering solutions in contact with HWSL.

The application of this classification system on geotechnical design and construction has proven effective in assessing geotechnical behaviour. A range of characteristic geotechnical parameters is provided per unit/geotechnical formation based on extensive data from several major projects in Doha. The authors' experience to date suggests that the use of the parameters presented in Table 5 in design has enabled predicting soil-structure interaction behaviours which were generally consistent with construction records, including instrumentations and monitoring data.

Drilling quality is considered crucial for the success of ground investigation programmes in Doha and the derivation of representative soil and rock parameters. Triple-tube drilling including inner split barrel or inner plastic liner is recommended, as well as a range of ground investigation best practices.

Differentiating dolomitic from non-dolomitic Simsima Limestone in compiling ground models has proved valuable in assessing the ground geotechnical characteristics. Non-dolomitic limestone is typically related to increased permeability, increased groundwater inflows and, on a site scale, higher weathering degree. A good correlation has not been found between non-dolomitic limestone layers and increased weathering at a borehole scale.

RQD and RMR values were found to produce a good representation of the ground conditions while the applicability of the GSI classification is believed to be limited.

Geophysical investigations and, in particular, the MASW method are mainly used for cavity identification. If the geophysical sections are calibrated with adjacent borehole data, they can also help in assessing weathered and fractured zones up to a depth of about $25 \mathrm{mbgl}$.

The MASW surveys used to inform this paper were carefully controlled for quality and strict application of the survey specification, and as a result, good correlations were made with geotechnical data. It was concluded that with a carefully specified method of field data acquisition, strict site supervision and careful correlation processes, the MASW data are considered a valid geophysical method to obtain a reasonable indication of the ground conditions in Doha.

MASW is not able to distinguish between SWSL and moderately weathered Simsima Limestone, with the classification system presented in this paper, but it can reliably identify large areas of weak material such as HWSL.

\section{Recommendations for further work}

The authors are of the view that the parameters presented in this paper are likely to be on the conservative side and recommend 
that further practical research is carried out towards improving the quality of in situ rock testing in Doha. This relates mainly to shear strength and stiffness properties of rock masses.

It would be very helpful to the construction industry in Qatar if a modification or alternative to the current GSI classification system could be proposed to help characterise the Doha rock units more accurately.

\section{Acknowledgements}

A large number of people have contributed to gathering the information this paper is based on. The information and guidance provided is the outcome of the collaborative hard work of a large regional team of ground engineers and geologists over more than 3 years.

\section{REFERENCES}

ASTM (2008) D 5607: Standard test method for performing laboratory direct shear strength tests of rock specimens under constant normal force. ASTM International, West Conshohocken, PA, USA.

ASTM (2010) D 7625: Standard test method for determination of abrasiveness of rock using Cerchar method. ASTM International, West Conshohocken, PA, USA.

ASTM (2014a) D 7012: Standard test methods for compressive strength and elastic moduli of intact rock core specimens under varying states of stress and temperatures. ASTM International, West Conshohocken, PA, USA.

ASTM (2014b) D 4428: Sandard test methods for crosshole seismic testing. ASTM International, West Conshohocken, PA, USA.

ASTM (2014c) D 7400: Standard test methods for downhole seismic testing. ASTM International, West Conshohocken, PA, USA.

ASTM (2016) D 4644: Standard test method for slake durability of shales and other similar weak rocks. ASTM International, West Conshohocken, PA, USA.

Bieniawski ZT (1989) Engineering Rock Mass Classifications: a Complete Manual for Engineers and Geologists in Mining, Civil, and Petroleum Engineering. Wiley, Hoboken, NJ, USA.

Bieniawski ZT (2011) Misconceptions in the applications of rock mass classifications and their corrections. ADI Seminar on Advanced Geotechnical Characterization for Tunnel Design, Madrid, Spain.

Brown ET (1981) Rock Characterization, Testing \& Monitoring: ISRM Suggested Methods. Pergamon, Oxford, UK.

BSI (1990) BS 1377:1990: Parts 1-9: Methods of test for soils for civil engineering purposes. BSI, London, UK.

BSI (2003) BS EN ISO 14686:2003: Hydrometric determinations. Pumping tests for water wells. Considerations and guidelines for design, performance and use. BSI, London, UK.

BSI (2005) BS EN ISO 22476-3:2005: Geotechnical investigation and testing. Field testing. Standard penetration test. BSI, London, UK.

BSI (2012) BS EN ISO 22282-4:2012: Geotechnical investigation and testing. Geohydraulic testing. Pumping tests. BSI, London, UK.
BSI (2015) BS 5930:2015: Code of practice for ground investigations. BSI, London, UK.

Carter TG, Diederichs MS and Carvalho JL (2008) Application of modified Hoek-Brown transition relationships for assessing strength and post yield behaviour at both ends of the rock competence scale. Journal of the Southern African Institute of Mining and Metallurgy 108(6): 325-338.

Cavellier C, Salatt A and Heuze Y (1970) Geological Description of the Qatar Peninsula (Explanation of the 1/100,000 Geological Maps of Qatar). Bureau de recherches geologiques et minieres, Paris, France.

Deere DU and Deere DW (1988) The rock quality designation (RQD) index in practice. In Rock Classification Systems for Engineering Purposes (Kirkdale L (ed.)). ASTM International. West Conshohocken, PA, USA, Special Technical Publication no. 984, pp. 91-101.

Fourniadis I (2010) Geotechnical characterization of the Simsima Limestone (Doha, Qatar). In Geoenvironmental Engineering and Geotechnics: Progress in Modeling and Applications GeoShanghai 2010 (He Q and Shen SL (eds)). American Society of Civil Engineers, Reston, VA, USA, Geotechnical Special Publication no. 204, pp. 273-278.

Franklin JA (1985) Suggested method for determining point load strength. International Journal of Rock Mechanics and Mining Sciences \& Geomechanics Abstracts 22(2): 51-60.

Galera JM, Álvarez M and Bieniawski ZT (2005) Evaluation of the deformation modulus of rock masses using RMR: comparison with dilatometer tests. In Underground Works under Special Conditions (Romana M, Perucho Á and Olalla C (eds)). CRC Press, Boca Raton, FL, USA, pp. 71-77.

Hoek E and Diederichs MS (2006) Empirical estimation of rock mass modulus. International Journal of Rock Mechanics and Mining Sciences 43(2): 203-215.

Hoek E, Kaiser PK and Bawden WF (1995) Support of Underground Excavations in Hard Rock. Taylor \& Francis, Abingdon, UK.

Hoek E, Marinos P and Benissi M (1998) Applicability of the geological strength index (GSI) classification for very weak and sheared rock masses: the case of the Athens Schist Formation. Bulletin of Engineering Geology and the Environment 57(2): 151-160.

Hoek E, Carranza-Torres C and Corkum B (2002) Hoek-Brown failure criterion - 2002 edition. In NARMS-TAC 2002: Mining and Tunnelling Innovation and Opportunity (Hammah R, Bawden W, Curran J and Telesnicki M (eds)). University of Toronto Press, Toronto, Canada, vol. 1, pp. 267-273.

Johnston IW (1991) Geomechanics and the emergence of soft rock technology. Australian Geomechanics 21: 3-25.

Latapie B and Lochaden AL (2016) Range of confining pressures for the Hoek-Brown criterion. Geotechnical Research 2(4): $148-154$.

Marinos V, Marinos P and Hoek E (2005) The geological strength index: applications and limitations. Bulletin of Engineering Geology and the Environment 64(1): 55-65. 
Geotechnical Research

Volume 3 Issue 3
Geology and geotechnical evaluation of

Doha rock formations

Karagkounis, Latapie, Sayers and Mulinti
Palmstrom A (2005) Measurements of and correlations between block size and rock quality designation (RQD). Tunnelling and Underground Space Technology 20(4): 362-377.

Park CB, Miller RD, Xia J and Ivanov J (2000) Multichannel seismic surface-wave methods for geotechnical applications. Proceedings of the First International Conference on the Application of Geophysical Methodologies and NDT to Transportation Facilities and Infrastructure, St Louis, MO, USA, pp. 11-15.
Park CB, Miller RD and Miura H (2002) Optimum field parameters of an MASW survey. Proceedings of the 2nd International Symposium of the Society of Exploration Geophysicists (SEG), Tokyo, Japan, pp. 22-23.

Sadiq AM and Nasir SJ (2002) Middle Pleistocene karst evolution in the state of Qatar, Arabian Gulf. Journal of Cave and Karst Studies 64(2): 132-139.

Williams P (2009) Plenary Lectures 2009 ICS proceedings. Proceedings of the 15th International Congress of Speleology, Kerrville, TX, USA.

\section{HOW CAN YOU CONTRIBUTE?}

To discuss this paper, please submit up to 500 words to the editor at journals@ice.org.uk. Your contribution will be forwarded to the author(s) for a reply and, if considered appropriate by the editorial board, it will be published as a discussion in a future issue of the journal. 